\title{
CROWDSOURCING CREATIVITY IN GOVERNMENT: STATE OF THE FIELD IN THE FOUR RESEARCH PARADIGMS
}

\author{
Łukasz SUŁKOWSKI ${ }^{1}$, Regina LENART-GANSINIEC (D ${ }^{1 *}$, Svitlana BILAN (D) ${ }^{2}$ \\ ${ }^{1}$ Institute of Public Affairs, Faculty of Management and Social Communication, Jagiellonian University, \\ Lojasiewicza str. 4, 30-348 Krakow, Poland \\ ${ }^{2}$ Institute of Public Affairs, Faculty of Management, Rzeszów University of Technology, \\ av. Powstancow Warszawy 10, 35-959 Rzeszow, Poland
}

Received 27 September 2019; accepted 25 February 2020

\begin{abstract}
Creativity, innovation, openness and involving citizens in decision making belong to a set of efforts undertaken by the government. This is possible thanks to crowdsourcing that is a tool to communicate with citizens and that is a source of knowledge and that provides new, creative ideas. However, despite the research intensity in the area of crowdsourcing creativity in government, the research results obtained to date are still ambiguous and fragmentary. Research on crowdsourcing government is often limited to interpretive traditions. This gives an incomplete picture of government crowdsourcing since three additional research paradigms are omitted: interpretative, postmodern, and critical. Our ambition is to raise awareness about the presence of many paradigms in crowdsourcing government research. The aim of this article is to present crowdsourcing government from the perspective of four paradigms by Gibson Burrell and Gareth Morgan. We are trying to achieve this by presenting a review of research on crowdsourcing government taking into consideration four paradigms: positivist, interpretative, critical, and postmodern. We suggest that a single paradigm is not able to provide a complete picture of crowdsourcing government, and thus we seek interactions between the paradigms and postulate multi-paradigmatic research that may lead to further development of knowledge.
\end{abstract}

Keywords: crowdsourcing creativity, crowdsourcing government, multiparadigm, research paradigm.

\section{Introduction}

The changes that have occurred over the past twenty years - related to the progressive democratization of public life, the need to involve citizens in decision making by the government, efficiency pressure, professionalization, and focus on innovation - make the conditions for the functioning of modern government characterized by high complexity, volatility and unpredictability (Zachorowska-Mazurkiewicz \& Sierotowicz, 2017; Kačerauskas, 2018; Stasiulis, 2017).

${ }^{\star}$ Corresponding author. E-mail: regina.lenart-gansiniec@uj.edu.pl 
It should be noted that these trends apply to the vast majority of world countries. For example, in Ukraine Antoniuk, Gernego, Dyba, Polishchuk, and Sybirianska (2017) analyzed studies on the innovative development of small and medium-sized enterprises and concluded that inefficient state support in this area was the main obstacle to business development. Shtuler, Cherlenyak, Domyshche-Medyanik, and Voitovych (2017) indicate that the state economic development policy should be based on the innovatization and intellectualization of activities and all macroeconomic projects. This will be a defining vector across the globe. With respect to involving citizens in government actions, Shkolnyk, Melnyk, and Mershchii (2018) state that the priority in socio-political transformations in Ukraine is introducing a qualitatively new type of relationship between citizens and authorities. Every person would be ensured real respect and protection of his rights and freedoms in these bodies' domain.

In relation to the signaled requirements and expectations, the government is forced to redefine methods and logic of action and to reach for solutions enabling not only contact with citizens, but also access to knowledge and new, creative ideas. One of such solutions refers to crowdsourcing that allows the government to access distributed, valuable knowledge found in virtual communities, to access their talents and creativity.

Crowdsourcing is paradigmatically anchored (Amankwatia, 2019; Estellés-Arolas \& González-Ladrón-de-Guevara, 2012), however, difficulties in ontology and epistemology were already signaled (Sivula \& Kantola, 2015). However, most studies conducted on crowdsourcing government are conducted in the interpretative paradigm. In the interpretive paradigm crowdsourcing is perceived as a subjective, unstable, unpredictable, uncontrollable, and socially constructed being. In this approach, crowdsourcing is defined as:

"generally described as a web-based activity that harnesses the creative contributions of a diverse large network of individuals (the crowd) through an open call requesting for their participation and contributions" (Stewart et al., 2010, p. 30).

From the perspective of the interpretive paradigm, crowdsourcing is based on cognitive loadings, stakeholder game, giving meaning, interpretation, reconstruction, and convergence performed by individuals, teams that identify ideas deemed worthy of attention (LenartGansiniec \& Sułkowski, 2018, Forthcoming). At the same time, the sense of satisfaction of the virtual community members is important because dissatisfaction can lead to abandoning crowdsourcing efforts. Accordingly, those who participate in crowdsourcing, both the initiator and members of the virtual community should take actions enabling the development of expression and creativity which is supposed to facilitate the ability to recall information in the future. Moreover, "crowdsourcing is a still a relatively new concept for businesses and science, and therefore requires the development of a holistic ontology" (Sivula \& Kantola, 2015, p. 637). In addition, knowledge about crowdsourcing is still like a "needle in a haystack, but the place where it appears is unknown" (Yu-Min Lin et al., 2014, p. 10).

Bearing in mind the above findings, the aim of the article is to present crowdsourcing from the perspective of four paradigms in management sciences, based on the Burrell and Morgan concept: functional, interpretative, critical, and post-modernist. The literature indicates that the selection of the paradigm for the study is one of the most important decisions made in any academic research (Sułkowski, 2012, p. 95). Paradigms are "coherent traditions of scientific research" and they mean a set of basic notions, beliefs, practices, ontological and 
epistemological assumptions, metaphors, and methods (Kuhn, 1996, p. 10), which leads to creating verifiable scientific knowledge based on verification. Paradigms are not templates or models, but a valid worldview, a way of seeing the world and they include common postulates connected with the nature of organizational reality, ways to name it, attitude to values, identification of researchers and references to management practice. In other words, a scientific paradigm can be understood as distinctive views on reality, a distinctive set of cognitive interests, theoretical frameworks, research questions, and methods used by scientists in a dialogue about knowledge development.

On this basis, a multi-paradigm approach to crowdsourcing is proposed, which is to constitute a framework for explaining the complexity of crowdsourcing, particularly its conceptualization, ontology, epistemology, and axiology. The rationale behind this approach is to understand the complex organizational phenomena that go beyond individual theories and paradigms and connect individuals and organizations. The literature indicates that:

"from the theoretical point of view, there is still a lot to do when it comes to the theo-

ry of crowdsourcing. [...] There is a lot of space to add value to this very current topic"

(Afuah \& Tucci, 2013).

In addition, understanding crowdsourcing based on just one paradigm may not be enough to capture the complexity and multi-dimensionality of crowdsourcing. Researchers postulate the use of many paradigms to account for many aspects of organizational reality (Kelemen \& Hassard, 2003), in particular that the theories of organization and management science are multi-paradigmatic (Sułkowski, 2013, p. 35). Our ambition is to encourage scientists to consider the contribution of other research paradigms to further develop knowledge of crowdsourcing government. This reflects our belief that research paradigms and epistemologies can be multiple and juxtaposed, and multi-paradigmatic research is possible - and even preferred. As a consequence, we end with a discussion about possible ways of conducting multi-paradigmatic research that may contribute to posing of new research questions and developing knowledge further.

\section{Literature review}

One of the most commonly used paradigm classifications in organizational research is the typology proposed by Burrell and Morgan (1979). It focuses on the ontological dichotomy of objectivist and subjectivist views of the nature of science, and the epistemological dichotomy of order and social change. Based on these two dichotomies, four paradigms are produced: functionalist, interpretive, critical, and post-modernist.

The functionalist paradigm is the dominant paradigm in the organizational research. The paradigm assumes verificationism, coherence, accumulation of knowledge, searching for one scientific method, division into dependent and independent variables, mathematical modeling, and quantifiability methodology (Sułkowski, 2012, p. 114). As a part of this paradigm, the researcher strives to obtain a reliable, objective, and universal knowledge that reflects reality. They allow for explaining and predicting individual and collective behavior. Social processes are of an objective and cause-and-effect nature, while organizations are understood as rational hierarchies and systems with formalized structures and identifiable boundaries and features (Sułkowski, 2012, p. 116). 
The interpretative paradigm assumes understanding, grasping, and interpreting the sense of reality from the point of view of an engaged observer or a member of the organization. The basis is the focus on describing, defining, and verifying the suitability and operation of the interdependence of social and organizational structures. Within this paradigm one strives to understand the phenomenon and to bring the researcher as closely as possible to what is being observed. Organizational processes as well as the whole reality is emerging, incomplete and consisting of social micro-practices. It is constructed by individuals in their minds and is rooted in the systems of values of the people who create them.

The critical paradigm assumes the existence of an objective social reality that requires constant reconstruction. According to this paradigm, researchers should strive to learn about social mechanisms, to discover the camouflaged reality, particularly of power, social inequalities, oppression of social structures, and domination (Sułkowski, 2012, p. 120). The critical stream indicates that organizations are disputable areas that shape the behavior of individuals aiming at disclosing the valid organizational order, managerial power and the interests of various social groups exercising power. According to this paradigm, a researcher acting within the limits of subjectivist epistemology is of a naturally normative position.

The post-modernist paradigm is based on subjectivism, ontology of becoming, cracks, and discontinuities. It is based on cognitive relativism, programme incoherence and mistrust towards science. According to this approach, the possibility of acquiring the truth is questioned, which makes it impossible to apply the scientific approach. Postmodernists aim to establish human activity and discourses (Grant et al., 2009) that conceptualize organizations as social temporary products of microprocesses, social order, and discursive patterns. The epistemology of postmodernism is connected with disagreement and the conviction that it is impossible to create an accurate description of the truth since there is no objective reality and there are no universal truths.

\section{Research section}

Following a principle of methodological rigor in reviewing literature (Pittaway et al., 2004), we conducted a systematic literature review. The literature of the subject was selected based on international databases, such as: EBSCO Information Services, ProQuest, Scopus, and Web of Science. Reaching for a few databases resulted from the desire to get a full picture of the issues being addressed. Database filtering criteria included the following keywords: "crowdsourcing government" and "paradigm". As a result of searching the bases, a total of over 3000 publications were found. Subsequently, the following restrictions were imposed on the identified articles: full-text, peer-reviewed publications, "crowdsourcing government" and "paradigm" in the title, abstract, and key words. Also duplicated publications, reviews, books, chapters in books, dissertations, and post-conference materials were eliminated. The search was narrowed down to scientific magazines in the field of management sciences. On this basis, 120 publications were selected. Subsequently, the abstracts of the selected articles were analyzed in order to find publications that directly concern the analyzed issues. After reading the abstracts, 83 publications were excluded, leaving 55 articles published in the years 2006-2018 for further analysis. 


\section{Key results}

When looking for crowdsourcing paradigms, four dominant paradigms in social sciences, functionalist, interpretative, critical, and post-modernist were taken into account, considering the ontological (a of world view with respect to a given domain), epistemological (a way of understanding and explaining how we know what we know), and axiological (the branch that studies judgments about value) assumptions. During the presentation of the paradigms of crowdsourcing attention was paid to the planned order of paradigms analysis.

\subsection{The functionalist paradigm}

In the functionalist paradigm, crowdsourcing is perceived as a real, objective, real, and concrete being. It is considered a synonym of information processing. For example, Otto Chrons and Sami Sundell $(2011$, p. 20) defined crowdsourcing as the concept of distributed work, in the context of very small microtasks, which is relatively new. The rise of fast networks and cheap terminals created the opportunity to break down complex tasks and send them to a distributed workforce for processing. "Crowdsourcing is also recognized as a way to access external knowledge" (Trompette et al., 2009), a tool supporting creative people and shaping an environment that encourages knowledge management (Blohm et al., 2013) and appropriation of results (Ebner et al., 2009).

Crowdsourcing consists of many elements that are interrelated and interdependent. We are discussing three basic components that are considered in the literature as the sine qua non conditions of crowdsourcing: (1) initiator - organization or person transferring a specific task to the virtual community, (2) virtual community - a person or masses of Internet users, carrying out thanks to the accumulation of knowledge and skills possessed by individuals, specific tasks directed for implementation by the initiator, and (3) online platform - a dedicated website, service, or portal that allows the initiator to connect with the virtual community and the implementation of a specific task by the engaged virtual community.

Crowdsourcing is a complex concept, taking into account elements, also areas understood as a cooperative and interdependent whole, and processes which enable the transformation of input data to output data (Zhao \& Zhu, 2014). The main issue of crowdsourcing systems is a problem directed by the organization to virtual communities, while the output focuses on obtaining a solution, task execution, evaluation, or problem solution by the initiator.

Crowdsourcing in the functionalist paradigm is considered from the point of view of motivation, management, coordination, adapting the organization to its implementation by changing organizational behavior. It boils down to the need for defining a set of basic and specific requirements or framework guidelines. Stewart, Huerta, and Sader (2009), for instance, analyze crowdsourcing from the point of view of designing and implementing principles. In turn, Leimeister, Huber, Bretschneider, and Krcmar (2009) analyze the ways of designing different types of crowdsourcing, taking into consideration crowdsourcing purpose. Others, however, realize that poorly managed crowdsourcing can bring many negative effects on the organization, for example related to the generation of excessive costs or the drainage of the organization's resources. The basis for adapting the organization to the implementation of crowdsourcing is the achievement of an adequate level of crowdsourcing maturity. 
The essence of crowdsourcing maturity is the transformation of the organization from closed to open to new resources of knowledge and skills as well as processing and interpreting information, which contributes to making changes. Others believe that thanks to crowdsourcing the organization can increase its absorption capacity (Schlagwein \& Bjørn-Andersen, 2014). This is confirmed by the research by Blohm, Leimeister, and Krcmar (2013), which indicates that it is important for the organization to develop mechanisms for assessing the acquired knowledge from the online community. Thus, others suggest that the acquired knowledge should be analyzed by an interdisciplinary team of internal experts (Riedl et al., 2013).

The analysis of the content of articles collected during the systematic review of the literature showed that crowdsourcing is treated as a mediator, which requires integration with the organization's strategies or as an independent variable that requires mediators. For instance, crowdsourcing is linked with the improvement of business processes, creation of open innovations (Brabham, 2008), building a competitive advantage, gaining access to innovation, information, crowd skills and work that are outside the organization (Brabham, 2008; Vukovic \& Bartolini, 2010), initiating cooperation and relations with virtual communities, problem solving, managing participation, increasing the organization's transparency and openness, organizational learning (Schlagwein \& Bjørn-Andersen, 2014).

In the functionalist paradigm the concepts often used in crowdsourcing are as follows: (1) system theory, describing crowdsourcing as a potential of large and open networks of people and (2) motivation theories, in particular: self-determination theory (Zhao \& Zhu, 2012), motivation crowding theory (Liu et al., 2011), the Motive-Incentive-Activation-Behavior Model (Briggs, 2006; Leimeister et al., 2009), protection motivation theory (Sandy Tsai et al., 2016), affordance theory and motivation theory (Choy \& Schlagwein, 2016), behavior change theory (Vries et al., 2016), and the theory of job design (Zheng et al., 2011). Researchers suggest that research considerations should additionally be conducted with the inclusion of the following theories: accountability theory (Vance et al., 2015), belief action outcome model, social cognitive theory (Bandura, 1978), and the theory of planned behavior (Bobbitt \& Dabholkar, 2001). All of these approaches perceive crowdsourcing as conscious, organized, coordinated, and managed activity.

The measurement of crowdsourcing in the functionalist approach should be quantifiable. According to the functionalist paradigm, the quantitative methodology becomes the best measurement tool. For example, Bayus (2013) analyzed the complexity of ideas addressed to virtual communities. Castillo, Mendoza, and Poblete (2013) studied management of the crowdsourcing project. On the other hand, Costa, Silva, Antunes, and Ribeiro (2013) proposed a framework for active learning using the crowdsourcing platform. Whereas, Ebner, Leimeister, and Krcmar (2009) presented an integrated concept of online competitions to exploit the potential of crowds in the real world.

Critics of the functionalist paradigm notice that the image of the examined reality is static and is based on descriptive questions, such as "how does $\mathrm{x}$ change from $\mathrm{y}$ ?" or explanatory questions like "does x cause $y$ ?". This approach enables checking whether the reality and the universal facts are obvious, whether the truth can exist objectively and independently of perception. However, this does not allow for identifying the meaning of a given concept. One can also notice the lack of autonomy of the social entity (Sułkowski, 2012, pp. 112-122). 
At the same time, the greatest weakness of the functionalist paradigm is the anthropomorphisation of crowdsourcing through theoretical unification, which makes it impossible to explain the details of connections and links between its perspectives, areas, or processes.

\subsection{The interpretative paradigm}

The results of the systematic literature review conducted indicate that the research on crowdsourcing in the interpretative paradigm is focused on understanding social norms, values, and behavior that affect the participants and the creative process. This is due to the fact that each organization has its own, often distinct cultural patterns and subcultures. For example, Rehman Shahid and Elbanna (2015, p. 1) stated that "changes recursively impacted the practices of crowdmapping". They also think that "there is a duality of change between the micro-practices of crowdmapping and the macro-practices of a humanitarian organization" (Rehman Shahid \& Elbanna, 2015, p. 1).

In the functionalist paradigm, two frequently used concepts in crowdsourcing are: (1) the methodological structuration theory (Pozzebon \& Pinsonneault, 2005), taking into account the structure and interactions in crowdsourcing and (2) conceptualizing organizations as cultures. The use of the methodological structuration theory aims at saying that crowdsourcing is established by the practices undertaken by social entities taking into account social life. This aims at realizing that members of the virtual community are diverse in terms of age, gender, ethnicity, culture, specialist knowledge, education, experience, beliefs, and location - hence their work is more valuable than any actions undertaken by an individual, even by an expert. As stated by Lakhani, Jeppesen, Lohse, and Panetta (2007) problem solvers extensively use prior experience and knowledge in their attempts at solving problems. That is why crowdsourcing can be compared to culture because, as in the case of culture, it is based on collective thinking and collective actions.

Due to the fact that crowdsourcing is socially constructed, it can lead to changes in the organizational processes and structures, and thus constructing organizational reality. Adjusting cultural norms of a given team or the whole organization increases the employees' commitment to accepting crowdsourcing. Otherwise, crowdsourcing will not be used, and employees may undertake sabotage activities. In other words, in the interpretive paradigm, the perception of reality is rooted in its context, and the employees' engagement and their identification with crowdsourcing brings tangible benefits to them and to the organization.

In the functionalism paradigm, two frequently used crowdsourcing concepts are: (1) methodological structuring theory (Pozzebon \& Pinsonneault, 2005), including structure and interaction in crowdsourcing and (2) conceptualization of organizations as cultures. Application of the structuring theory methodology allows us to say that crowdsourcing is determined by the practices used by social actors, taking into account social life.

In the interpretive paradigm, crowdsourcing is based on the meanings and social communication created by the social group, social relations, where members of virtual communities are involved in the activity - which affects the performance and quality of work of other team members. Social relations combine the actions of the individual with the activities of other members of the virtual community through behavior, commitment, trust, entering into 
dialogue, and job satisfaction. For instance, Stefanick and LeSage (2005) analyzed a crowdsourcing project named MuniMall. It was an online meeting place created by the University of Alberta, Canada and the Alberta Public Affairs Bureau. The main aim of this undertaking was to provide some opportunity to enter into a discussion between citizens and representatives of the office. However, the MuniMall project was unsuccessful and the virtual community was not interested in any interacting.

As indicated by the cited systematic review of literature carried out by Hossain and Kauranen (2015), out of 50 analyzed publications - in 10 articles, researchers applied for qualitative research (20\%). In most of those articles, interviews were used to collect data, while in one case focus studies were conducted. Qualitative research focused on the assessment of crowdsourcing as a strategy for supplementing internal competences or involving various stakeholders by using crowdsourcing.

The weakness of the interpretive paradigm is the underestimation of the constraints imposed on individuals by organizational structures. In this paradigm, the focus is on describing interdependencies in the assumed social and organizational structures, while marginalizing the final effect of a given activity. Also, no attention is paid to independent and influential factors that may affect the success of a crowdsourcing initiative, which does not allow for reaching an emerging and liquid reality.

\subsection{The critical paradigm}

In the critical paradigm, crowdsourcing is perceived as a subjective and oppressive being. In addition, according to this paradigm, homogeneity of individual and collective identities occurs, leveling the management of one's own interests with the interests of organizations and organizational cultures that reproduce the dominant discourses (Grant et al., 2009). This leads to the emancipation of devalued social groups, reducing the inequality and oppressiveness of the organization.

In the critical paradigm, the concepts often used in crowdsourcing are: (1) Marxian concepts of dialectics, (2) determinism of structure over superstructure, (3) oppression inherent in human condition (Hardy \& Clegg, 1997), (4) the Frankfurt School, and (5) the work of Jürgen Habermas (Willmott, 2003). Brabham (2008, p. 76), for example, perceives crowdsourcing as a manifestation of the resistance of members of the virtual community to the manipulation of the organization that directs tasks and problems to be solved, barriers, and regulations regarding access to participation in crowdsourcing applications. Brabham sees this as crowdslapping, where:

\footnotetext{
"for instance, one cannot submit a design idea to threadless without the graphics and editing software necessary to upload to the company's template, and a digital camera and knowledge of its use - is required of iStockphoto photographers" (2009, p. 87).
}

In this approach "the crowd turns against the crowdsourcer" (Howe, 2010), and crowdsourcing alone is perceived through the prism of control and coercion. In practice, members of the virtual community can display passivity, frustration and take actions that are harmful and destructive for the organization - in the case of an excess of users taking part in a crowdsourcing initiative or too many ideas submitted by others. 
He realizes that crowdsourcing can be compared to social inequalities, where the organization as the owner of the means of production, appropriates the difference between the new value created by the employees and the labor costs in the form of employees' remuneration. As part of the critical paradigm, researchers strive to discover changes in reality, as well as objectively and intersubjectively existing relationships of domination. This means that crowdsourcing is considered from the point of view of manipulating the members of the virtual community, cultural relativism, the processual vision of organizing, distributing power, and exposing the organizational order. In the critical paradigm, crowdsourcing is a way to support organizational change, where researchers are agents of such changes. For example, Zhao, Zhang, and Song (2018) explored the field and action research, where they collaborated with the employees of malls, libraries, archives, and museums on the project The Shengxuanhuai Manuscript Transcription Initiative (Transcribed Sheng for Short). Hills (2015), however, collaborated with schools in the field of crowdsourcing implementation. Bryer and Cooper (2012) notice that the cost of involving citizens may drain resources from professional administration work. They state that the reasons behind this may be the capabilities and skills of the citizens and the method crowdsourcing is implemented.

The weakness of the critical paradigm is the lack of empirical research and a deterministic view of social and organizational structures (Alvesson \& Deetz, 1996). Organizational reality, but also crowdsourcing alone are oppressive. The basis is the pursuit of power and domination over others. It is based on the actions of privileged, dominant units; however, their operation is not transparent and difficult to identify.

\subsection{The post-modernist paradigm}

In the post-modernist paradigm, crowdsourcing is a subjective being. For example, Redi, Hoßfeld, Korshunov, Mazza, Povoa, and Keimel (2013) found this to be to "a powerful tool for gathering subjective ground truth for large multimedia collections". The foundation here is discourse and it is a tool for describing and presenting reality. It is also useful for analyzing communication and practices of virtual communities. The post-modernist vision of crowdsourcing is also focused on communication practices of virtual communities, narratives, and discussions induced into forms of organization and existing structures of the initiative. Ultimately, crowdsourcing is captured in the context of language, metaphors, paradoxes, and textuality.

In the post-modernist paradigm, the most frequently indicated are criticisms of the organization's oppression towards virtual communities, violence, unethical behavior, managerialism, and consumerism. It focuses on knowledge, inquiry, language, dialogue, and discourse, and that the individual work of a virtual community member translates into jointly assigning meanings through text, intertextuality, and storytelling.

The literature indicates that crowdsourcing is of a paradoxical nature (Piezunka \& Dahlander, 2015). In particular, these paradoxes may concern virtual communities. For example, when a community surpasses a certain number of active users, the idea of generation is negatively affected. It comes down to the fact that the excess of ideas, users, and feedback between the organization and the virtual community may discourage them from creating and sending ideas. It is said that this increases their stress and causes uncertainty and negatively 
influences their motivation to take part in the creative process. The other paradox concerns the accessibility of ideas on the crowdsourcing platform. On the one hand, it can be some inspiration and motivation for members of the virtual community, but on the other it can reduce creativity and production and cause distraction. Internet users may in fact be influenced or even inspired by another person's idea and unknowingly propose convergent ideas. This means that access to too many ideas of others may lead to dissatisfaction, lower productivity (Chua \& Iyengar, 2008), and inertia.

However, restricting access to other ideas leads to sending low quality solutions and dissatisfaction with participation in crowdsourcing. Another paradox concerns reaching out to the virtual communities for innovative ideas. This leads to the conclusion that members of the virtual community should not only focus on coming up with new solutions, but also refer their ideas to what the organization already knows, which would paradoxically require those people to be able to come up with innovative ideas, but also have knowledge of the organization's functioning and structures.

The weakness of the postmodern paradigm is the lack of empirical research that takes into account the problem of discourse or paradoxes in crowdsourcing. In addition, this paradigm is characterized by cognitive and cultural relativism, subjectivism, deconstruction of structures, organizational routines, and social context - which leads to the fact that it is "highly theoretical and generalized and remains quite esoteric” (Alvesson \& Deetz, 1996, p. 212).

\subsection{Where the studies from the four paradigms can meet}

The analysis of the paradigms of social sciences indicates that despite the differences, the individual paradigms should be considered as complementary and, as Dennis A. Gioia and Evelyn Pitre claim, indicate the transition points:

"in a strict sense, then, the paradigms do not constitute hard-and-fast domains. The boundaries between paradigms are therefore more usefully conceived as transition zones" (1990, p. 592).

The diagram of the transition between the paradigms was grouped taking into account the ontological and epistemological premises (Figure 1).

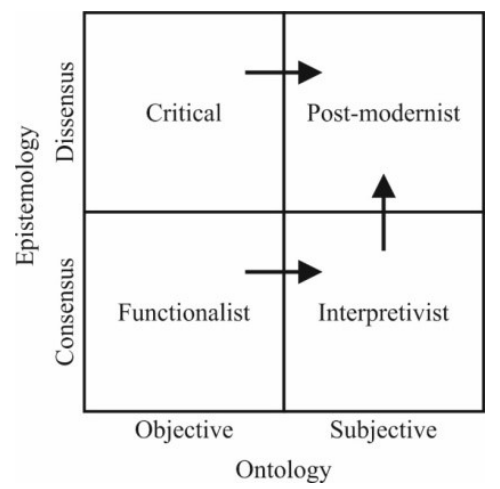

Figure 1. Transition zones between crowdsourcing paradigms (source: created by authors) 
Research inspired by different research paradigms may enrich the understanding of crowdsourcing government ensuring a multi-aspect picture of the phenomenon. Moreover, the mutual interaction of the paradigms may lead to posing new research questions and developing a new theory.

In the demarcation between the paradigms, a matrix proposed by Burrell and Morgan was used. In the research process four main positions were adopted methodologically: functionalist, interpretative, critical, and post-modernist. Bearing in mind the above and the recommendations of Gioia and Pitre (1990) and Burrell and Morgan (1979), three transition zones were proposed: the functionalist-interpretative paradigm, critical-post-modernist, and interpretative-postmodernist paradigm. During the deliberations, the functionalist-critical paradigm was omitted, which is due to two reasons. First of all, as Gioia and Pitre point out that,

"these paradigmatic differences occur along a regulation change dimension that might be more usefully characterized in terms of degree of change (ranging from incremental to radical change, rather than from stability to radical change)" (1990, p. 592).

Secondly,

"although we see only limited similarity in the writings of these two paradigms [...], this lack of similarity might occur simply because of their markedly different outlooks" (Gioia \& Pitre, 1990, p. 594).

The literature indicates that there are several elements common in the functionalist and interpretive paradigm. In particular we mean social interactions and leadership here. First of all, according to the interpretative paradigm social processes are based on human cognition and social interactions at the group and organizational levels. In turn, in the case of the functionalist paradigm, maintaining social order is possible thanks to the exchange between elements of the social system (Sułkowski, 2013, p. 43). In this perspective, crowdsourcing is based on the organization's interaction with the virtual community, crowd wisdom, communication, collaboration, trust, the organization's openness to the environment, and an organizational culture that is open to change.

Crowdsourcing enables the organization to gain knowledge possessed by the virtual community members and to reach for their ingenuity and creativity. Nevertheless, it is the management staff that initiate and control implementation of crowdsourcing. Thus, it is possible to point to the combination of a functionalist and interpretive paradigm in the context of the initiation of social processes by the management staff and the combination of knowledge at the individual and group level, as well as the acceptance of the implementation of new solutions by employees. It is believed that the employees of the organization can be a driving force of crowdsourcing, and their engagement affects its effectiveness. In other words, crowdsourcing will work if the employees of a public organization are convinced that their role is "to find the areas where (the crowd will) want to work and contribute" (Noveck, 2009, p. 41). Appropriate motivation of the employees may make new solutions, ideas acquired from the crowd accepted, disseminated, and assimilated, while knowledge will be used to propose improvements in their workplace or for the entire division/department and building their 
own reputation. It is also important to recognize significance of the perception of benefits by the employees, knowledge of the operation of the crowdsourcing platform owned by the organization, active participation in the planning of crowdsourcing implementation (Fernandez \& Pitts, 2011), atmosphere at work, support from colleagues and manager, investment in training (Nečadová \& Scholleová, 2011), and experience and technical skills. Seemingly, the postmodern and critical paradigm shows more differences than common features: the critical paradigm presupposes the existence of an objective social reality, while the postmodern paradigm - subjectivism and relativism. Gioia and Pitre (1990, p. 594) think, however, that "these disparate assumptions can be bridged at the transition zone, for reasons similar to those offered for the bridge between interpretivism and functionalism". In their opinion, the link between objectivity and subjectivism involves making changes and structuring, which includes negotiated order, reflexivity, structuring structures, relative independence, principles, ceremonies, and rites.

First of all, both the critical and postmodern paradigms refer to the need to introduce changes in the organization. At the same time, in the critical trend:

"positive change leads to emancipation of disadvantaged social groups, reduction of inequality and oppressiveness of the organization and obliteration of false consciousness" (Sułkowski, 2016, pp. 38-39),

whereas in postmodernism

"the nature of change is subjective and permanent because it is associated with spontaneous, uncontrolled, and unconscious flows of interpretation, narration, sense, and power between various intersecting discourses" (Sułkowski, 2016, pp. 35-36).

Secondly, a link between the objectivity of the critical paradigm and the subjectivism of postmodernism is structuralization. In short, structuralization consists in the separation of structure, which leads to the shaping and arrangement of elements in such a way as to constitute a hierarchical system. The literature perceives virtual community to be the most important element of a crowdsourcing project (Brabham, 2012), which is defined as a diverse, heterogeneous, and undefined in terms of knowledge and skills large population of people that exceeds geographical, political, and systemic constraints and performs voluntarily specific tasks in cyberspace to achieve mutual interests and goals. Structuralization also includes tasks addressed to the virtual community. A crowdsourcing task can be defined as an abstract description of the work content or an illustration of a work process that can be divided and combined. Such definition entails further consequences with the academics: researchers often focused on the features or functions of the task itself and its characteristics, but also its attributes, behaviors, or activities connected with its designing, attribution to a specific virtual community or evaluation of the effectiveness of their implementation.

The literature indicates that both the interpretative and postmodernist paradigms belong to a single paradigm that is related to interpretation. What combines these two paradigms is the meaning of language and its institutional use, including reaching for language games and the use of actor-network theory. First, crowdsourcing is based on virtual communities that build their own way of communication and discourse. Fayard and DeSanctis (2005) highlight that virtual communities gathered around the crowdsourcing initiative use specific language 
games, their own language style, interaction patterns and a sense of collective identity. They enable communication and provide a method of sharing knowledge and interpret information. This is confirmed by the findings of Fayard and DeSanctis (2005) who claim that the language game should be designed. In practice, it boils down to the fact that the organization designs the way the virtual community participates, the way it communicates, and also establishes a moderator who

\footnotetext{
"welcomes newcomers, stirs up the discussion, and sets the pattern for greetings and closings - is instrumental in starting the forum and building the stage for lively interactions" (Fayard \& DeSanctis, 2005).
}

This theory allows for discovering collective social engineering processes, description and explanation of relationships between people, institutions, and artifacts connected with contracts and exchanges (Spinuzzi, 2008). Clay Spinuzzi claims that organizations are historically and socially-evolved collections of action networks, which are referred to as a set of activities that are heterogeneous, repeatedly connected, transforming and have a simple interface to solve large complex problems (2008, p. 187).

\section{Conclusions}

The aim of the article was to present crowdsourcing government from the perspective of four paradigms by Burrell and Morgan. Our intention was to increase reflection on the crowdsourcing government paradigms. Crowdsourcing government is currently based on the interpretative paradigm (Brabham, 2012). There are also works that include crowdsourcing in the positivist, critical, and postmodern paradigms. We found the common features of these conceptualizations.

Although, all paradigms confirm that the basis of crowdsourcing is the interactions of the organization with the virtual community, the difference of emphasis can be noticed. For example, the functionalists emphasize that crowdsourcing is a real, objective, and concrete entity. However, the emphasis is on structures, and collective and cognitive processes. In the interpretive paradigm, however, crowdsourcing is perceived as a subjective, unstable, unpredictable, uncontrolled entity constructed by interaction and social behavior. In critical terms, however, crowdsourcing is a subjective and oppressive entity. With respect to the postmodernists, crowdsourcing is a textual interaction that is expressed in discourses between its individual areas. Our review of works on crowdsourcing government contributes to the search for interaction between paradigms. We propose the following three transition zones: functionalist-interpretative, critical-post-modernist, and interpretative-post-modernist. These zones explain limitations of individual paradigms and identify their potential complementarity. In the functionalist-interpretative transition, we notice the focus on social interaction, communication, collaboration, trust, and organization openness. In the critical-post-modernist transition, we identify the focus on making changes to the organization, particularly those related to performance, flexibility, and reorganization of organizational procedures. Structuralization is of importance here. In the interpretative-post-modernist transition, we point to language games and the action-network theory. Discourses and discursive practices shape the communication of virtual communities with each other and between the crowdsourcing initiator. 
We believe that the interactions between paradigms can lead to exciting and groundbreaking studies on crowdsourcing government. It should be highlighted that taking up consideration of crowdsourcing is important not only from the point of view of theory but also practice because it is stated that organizations that ignore crowdsourcing and underestimate the power of virtual communities, risk losing chances of survival. In addition, the adoption of many paradigms allows for the disclosure of crowdsourcing features that in other cases may remain hidden for researchers and practitioners. The involvement of many paradigms also encourages practitioners to seek new solutions and combine opposing positions.

The conclusions from the conducted analyses and research are of an applicatory nature. They can be used by the management staff of the municipal offices using crowdsourcing or planning to do so. Firstly, the results will help identify the key drivers of crowdsourcing success. Secondly, they enable managing the crowdsourcing initiative, achieving potential benefits, and reducing risk factors. Thirdly, "consultants and clients become aware of their own taken-for granted perspectives" (Harrison \& Shirom, 1999, pp. 199-242).

\section{References}

Afuah, A., \& Tucci, Ch. L. (2013). Value capture and crowdsourcing. Academy of Management Review, 38(3), 457-460. https://doi.org/10.5465/amr.2012.0423

Alvesson, M., \& Deetz, S. (1996). Critical theory and postmodernism approaches to organizational studies. In S. R. Clegg, C. Hardy, \& W. R. Nord (Eds.), Handbook of Organization Studies (pp. 191217). SAGE Publications.

Amankwatia, T. B. (2019). Massive open program evaluation: Crowdsourcing's potential to improve e-learning quality. In Information Resources Management Association (Ed.), Crowdsourcing: Concepts, methodologies, tools, and applications (pp. 53-74). IGI Global. https://doi.org/10.4018/978-1-5225-8362-2.ch004

Antoniuk, L., Gernego, I., Dyba, V., Polishchuk, Y., \& Sybirianska, Y. (2017). Barriers and opportunities for hi-tech innovative small and medium enterprises development in the $4^{\text {th }}$ industrial revolution era. Problems and Perspectives in Management, 15(4), 100-113. https://doi.org/10.21511/ppm.15(4).2017.09

Bandura, A. (1978). Self-efficacy: Toward a unifying theory of behavioral change. Advances in Behaviour Research and Therapy, 1(4), 139-161. https://doi.org/10.1016/0146-6402(78)90002-4

Bayus, B. L. (2013). Crowdsourcing new product ideas over time: An Analysis of the Dell IdeaStorm Community. Management Science, 59(1), 226-244. https://doi.org/10.1287/mnsc.1120.1599

Blohm, I., Leimeister, J. M., \& Krcmar, H. (2013). Crowdsourcing: How to benefit from (Too) many great ideas. MIS Quarterly Executive, 12(4), 199-211.

Bobbitt, L. M., \& Dabholkar, P. A. (2001). Integrating attitudinal theories to understand and predict use of technology-based self-service: The internet as an illustration. International Journal of Service Industry Management, 12(5), 423-450. https://doi.org/10.1108/EUM0000000006092

Brabham, D. C. (2008). Crowdsourcing as a model for problem solving: An Introduction and cases. Convergence: The International Journal of Research into New Media Technologies, 14(1), 75-90. https://doi.org/10.1177/1354856507084420

Brabham, D. C. (2012). The myth of amateur crowds: A Critical discourse analysis of crowdsourcing coverage. Information, Communication and Society, 15(3), 394-410.

https://doi.org/10.1080/1369118X.2011.641991 
Briggs, R. O. (2006). On theory-driven design and deployment of collaboration systems. International Journal of Human-Computer Studies, 64(7), 573-582. https://doi.org/10.1016/j.ijhcs.2006.02.003

Bryer, Th. A., \& Cooper, T. L. (2012). H. George Frederickson and the dialogue on citizenship in public administration. Public Administration Review, 72(1), 108-116. https://doi.org/10.1111/j.1540-6210.2012.02632.x

Burrell, G., \& Morgan, G. (1979). Sociological paradigms and organizational analysis: Elements of the sociology of corporate life. Series: Routledge Revivals. Heinemann Educational Books.

Castillo, C., Mendoza, M., \& Poblete, B. (2013). Predicting Information credibility in time-sensitive social media. Internet Research, 23(5), 560-588. https://doi.org/10.1108/IntR-05-2012-0095

Choy, K., \& Schlagwein, D. (2016). Crowdsourcing for a better world: On the relation between IT affordances and donor motivations in charitable crowdfunding. Information Technology and People, 29(1), 221-247. https://doi.org/10.1108/ITP-09-2014-0215

Chrons, O., \& Sundell, S. (2011, August). Digitalkoot: Making old archives accessible using crowdsourcing. In von L. Ahn, \& P. G. Ipeirotis (Eds.), Human computation: Papers from the 2011 AAAI workshop (pp. 20-25). San Francisco, California, United States.

Chua, R. Y.-J., \& Iyengar, Sh. S. (2008). Creativity as a matter of choice: Prior experience and task instruction as boundary conditions for the positive effect of choice on creativity. Journal of Creative Behavior, 42(3), 164-180. https://doi.org/10.1002/j.2162-6057.2008.tb01293.x

Costa, J., Silva, C., Antunes, M., \& Ribeiro, B. (2013). Customized crowds and active learning to improve classification. Expert Systems with Applications, 40(18), 7212-7219.

https://doi.org/10.1016/j.eswa.2013.06.072

Ebner, W., Leimeister, J. M., \& Krcmar, H. (2009). Community engineering for innovations: The ideas competition as a method to nurture a virtual community for innovations. R\&D Management, 39(4), 342-356. https://doi.org/10.1111/j.1467-9310.2009.00564.x

Estellés-Arolas, E., \& González-Ladrón-de-Guevara, F. (2012). Towards an integrated crowdsourcing definition. Journal of Information Science, 38(2), 189-200. https://doi.org/10.1177/0165551512437638

Fayard, A.-L., \& DeSanctis, G. (2005). Evolution of an online forum for knowledge management professionals: A language game analysis. Journal of Computer-Mediated Communication, 10(4). https://doi.org/10.1111/j.1083-6101.2005.tb00265.x

Fernandez, S., \& Pitts, D. W. (2011). Understanding employee motivation to innovate: Evidence from front line employees in United States federal agencies. Australian Journal of Public Administration, 70(2), 202-222. https://doi.org/10.1111/j.1467-8500.2011.00726.x

Gioia, D. A., \& Pitre, E. (1990). Multiparadigm perspectives on theory building. Academy of Management Review, 15(4), 584-602. https://doi.org/10.5465/amr.1990.4310758

Grant, D., Iedema, R., \& Oswick, C. (2009). Discourse and critical management studies. In M. Alvesson, T. Bridgman, \& H. Wilmott (Eds.), The Oxford handbook of critical management studies (pp. 213-231). Oxford University Press. https://doi.org/10.1093/oxfordhb/9780199237715.003.0010

Hardy, C., \& Clegg, S. (1997). Relativity without relativism: Reflexivity in post-paradigm organization studies. British Journal of Management, 8(s1), 5-17. https://doi.org/10.1111/1467-8551.8.s1.2

Harrison, M. I., \& Shirom, A. (1999). Organizational diagnosis and assessment: Bridging theory and practice. Sage Publications, Inc.

Hills, Th. T. (2015). Crowdsourcing content creation in the classroom. Journal of Computing in Higher Education, 27(1), 47-67. https://doi.org/10.1007/s12528-015-9089-2

Hossain, M., \& Kauranen, I. (2015). Crowdsourcing: A comprehensive literature review. Strategic Outsourcing: An International Journal, 8(1), 2-22. https://doi.org/10.1108/SO-12-2014-0029

Howe, J. (2010). Crowdsourcing. https://crowdsourcing.typepad.com/cs/2006/06/neo_neologisms.html 
Kačerauskas, T. (2018). Indices of creative economy: Critique of R. Florida's creativity indices. Economics and Sociology, 11(4), 280-288. https://doi.org/10.14254/2071-789X.2018/11-4/18

Kelemen, M., \& Hassard, J. (2003). Paradigm plurality: Exploring past, present, and future trends. In R. Westwood \& S. Clegg (Eds.), Debating organization: Point-counterpoint in organization studies (pp. 73-82). Blackwell Publishing Ltd.

Kuhn, T. S. (1996). The structure of scientific revolutions. University of Chicago Press. https://doi.org/10.7208/chicago/9780226458106.001.0001

Lakhani, K. R., Jeppesen, L. B., Lohse, P. A., \& Panetta, J. A. (2007). The value of openness in scientific problem solving. Working knowledge: Business research for business leaders (Working Paper No. 07-050). https://www.hbs.edu/faculty/Publication\%20Files/07-050_1b57659d-78f04686-a764-925531f05a7b.pdf

Leimeister, J. M., Huber, M., Bretschneider, U., \& Krcmar, H. (2009). Leveraging crowdsourcing: Activation-supporting components for IT-based ideas competition. Journal of Management Information Systems, 26(1), 197-224. https://doi.org/10.2753/MIS0742-1222260108

Lenart-Gansiniec, R., \& Sułkowski, Ł. (2018). Crowdsourcing - A new paradigm of organizational learning of public organization. Sustainability, 10, 3359. https://doi.org/10.20944/preprints201808.0467.v1

Lenart-Gansiniec, R., \& Sułkowski, Ł. (2018). Organizational learning and value creation in local governance: The mediating role of crowdsourcing. The Learning Organization. (Forthcoming).

Liu, Ch.-Ch., Liang, T.-P., Rajagopalan, B., \& Sambamurthy, V. (2011, 7-11 July). The crowding effect of rewards on knowledge-sharing behavior in virtual communities. In Proceedings of the Pacific Asia Conference on the $15^{\text {th }}$ Information Systems (PACIS) (pp. 1-15). Brisbane, Australia.

Nečadová, M., \& Scholleová, H. (2011). Motives and barriers of innovation behaviour of companies. Economics and Management, 16, 832-838.

Noveck, B. S. (2009). Wiki government: How technology can make government better, democracy stronger, and citizens more powerful. Brookings Institution Press.

Piezunka, H., \& Dahlander, L. (2015). Distant search, narrow attention: How crowding alters organizations' filtering of suggestions in crowdsourcing. Academy of Management Journal, 58(3), 856-880. https://doi.org/10.5465/amj.2012.0458

Pittaway L., Robertson, M., Munir, K., Denyer, D., \& Neely, A. (2004). Networking and innovation: A systematic review of the evidence. International Journal of Management Reviews, 5-6(3-4), 137168. https://doi.org/10.1111/j.1460-8545.2004.00101.x

Pozzebon, M., \& Pinsonneault, A. (2005). Challenges in Conducting empirical work using structuration theory: Learning from IT research. Organization Studies, 26(9), 1353-1376. https://doi.org/10.1177/0170840605054621

Redi, J., Hoßfeld, T., Korshunov, P., Mazza, F., Povoa, I., \& Keimel, Ch. (2013, 21 October). Crowdsourcing-based multimedia subjective evaluations: A case study on image recognizability and aesthetic appeal. In Proceedings of the $2^{\text {nd }}$ International ACM Workshop on Crowdsourcing for Multimedia, CrowdMM'13 (pp. 29-34). Barcelona, Spain. https://doi.org/10.1145/2506364.2506368

Rehman Shahid, A., \& Elbanna, A. (2015, 26-29 May). The impact of crowdsourcing on organizational practices: The case of crowdmapping. In Proceedings of the $23^{\text {rd }}$ European Conference on Information Systems (ECIS 2015) (pp. 1-16). Münster, Germany.

Riedl, Ch., Blohm, I., Leimeister, J. M., \& Krcmar, H. (2013). The effect of rating scales on decision quality and user attitudes in online innovation communities. International Journal of Electronic Commerce, 17(3), 7-36. https://doi.org/10.2753/JEC1086-4415170301

Sandy Tsai, H., Jiang, M., Alhabash, S., LaRose, R., Rifon, N. J., \& Cotton, Sh. R. (2016). Understanding online safety behaviors: A protection motivation theory perspective. Computers and Security, 59, 138-150. https://doi.org/10.1016/j.cose.2016.02.009 
Schlagwein, D., \& Bjørn-Andersen, N. (2014). Organizational learning with crowdsourcing: The revelatory case of LEGO. Journal of the Association for Information Systems, 15(11), 754-778. https://doi.org/10.17705/1jais.00380

Shkolnyk, I., Melnyk T., \& Mershchii, B. (2018). Transparency of the budget process as a prerequisite for financial decentralization in Ukraine. Public and Municipal Finance, 7(1), 12-20. https://doi.org/10.21511/pmf.07(1).2018.02

Shtuler, I., Cherlenyak, I., Domyshche-Medyanik, A., \& Voitovych, S. (2017). Conditions of formation and stimulation of the activators of innovative development of Ukraine. Problems and Perspectives in Management, 15(4), 150-160. https://doi.org/10.21511/ppm.15(4).2017.13

Sivula, A., \& Kantola, J. (2015). Ontology focused crowdsourcing management. Procedia Manufacturing, 3, 632-638. https://doi.org/10.1016/j.promfg.2015.07.286

Spinuzzi, C. (2008). Network: Theorizing knowledge work in telecommunications. Cambridge University Press. https://doi.org/10.1017/CBO9780511509605

Stasiulis, N. (2017). The idea of the creative society and the development of creative industries. Economics and Sociology, 10(2), 217-226. https://doi.org/10.14254/2071-789X.2017/10-2/16

Stefanick, L., \& LeSage Jr., E. (2005). Limitations to developing virtual communities in the public sector: A local government case study. Canadian Public Administration, 48(2), 231-250. https://doi.org/10.1111/j.1754-7121.2005.tb02189.x

Stewart, O., Huerta, J. M., \& Sader, M. (2009, 28 June). Designing crowdsourcing community for the enterprise. HCOMP '09: Proceedings of the ACM SIGKDD Workshop on Human Computation (pp. 50-53). New York City, United States. https://doi.org/10.1145/1600150.1600168

Stewart, O., Lubensky, D., \& Huerta, J. M. (2010, 25 July). Crowdsourcing participation inequality: A SCOUT model for the enterprise domain. In HCOMP '10: Proceedings of the ACM SIGKDD Workshop on Human Computation (pp. 30-33). Washington, D.C., United States. https://doi.org/10.1145/1837885.1837895

Sułkowski, Ł. (2012). Epistemologia i metodologia zarządzania. Polskie Wydawnictwo Ekonomiczne.

Sułkowski, Ł. (2013). Metodologia zarządzania - od fundamentalizmu do pluralizmu. In W. Czakon (Ed.), Podstawy metodologii badań w naukach o zarzadzaniu (pp. 35-36, 38-39, 43). Wolters Kluwer.

Trompette, P., Chanal, V., \& Pelissier, C. (2009, 10-12 July). Crowdsourcing as a way to access external knowledge for innovation: Control, incentive and coordination in hybrid forms of innovation. In Proceedings of $24^{\text {th }}$ EGOS Colloquium. Amsterdam, Netherlands. https://halshs.archives-ouvertes. fr/halshs-00367373/document

Vance, A., Lowry, P. B., \& Eggett, D. L. (2015). Increasing accountability through the user interface design artifacts: A new approach to addressing the problem of access-policy violations. MIS Quarterly, 39(2), 345-366. https://doi.org/10.25300/MISQ/2015/39.2.04

Vries, de R. A. J., Truong, K. P., Kwint, S., Drossaert, C. H. C., \& Evers, V. (2016, 7-12 May). Crowddesigned motivation: Motivational messages for exercise adherence based on behavior change theory. CHI '16: Proceedings of the $201634^{\text {th }}$ Annual CHI Conference on Human Factors in Computing Systems (pp 297-308). San Jose, California, United States.

Vukovic, M., \& Bartolini, C. (2010, October). Towards a research agenda for enterprise crowdsourcing. In T. Margaria, \& B. Steffen (Eds.), Leveraging Applications of Formal Methods, Verification and Validation: Technologies for Mastering Change (pp. 425-434). In $4^{\text {th }}$ International Symposium on Leveraging Applications, ISoLA 2010. Heraklion, Crete, Greece. Springer-Verlag. https://doi.org/10.1007/978-3-642-16558-0_36

Willmott, H. (2003). Organization theory as a critical science? Forms of analysis and "New Organizational Forms". In H. Tsoukas \& Ch. Knudsen (Eds.), The Oxford handbook of organization theory: Meta-theoretical perspectives (pp. 88-112). Oxford University Press. 
Yu-Min Lin, A., Huynh, A., Lanckriet, G., \& Barrington, L. (2014). Crowdsourcing the unknown: The satellite search for Genghis Khan. PloS One, 9(12). https://journals.plos.org/plosone/article/ file? id=10.1371/journal.pone.0121045\&type=printable

Zachorowska-Mazurkiewicz, A., \& Sierotowicz, T. (2017). Women, men and creativity in higher education sector - Comparative studies of leading EU and ECE countries. Journal of International Studies, 10(3), 105-119. https://doi.org/10.14254/2071-8330.2017/10-3/8

Zhao, Y. Ch., \& Zhu, Q. (2014). Effects of extrinsic and intrinsic motivation on participation in crowdsourcing contest: A perspective of self-determination theory. Online Information Review, 38(7), 896-917. https://doi.org/10.1108/OIR-08-2014-0188

Zhao, Y., Zhang, X., \& Song, X. (2018). Crowdsourcing in the digital humanities: An action research on the Shengxuanhuai manuscript transcription. Illinois Digital Environment for Access to Learning and Scholarship. https://www.ideals.illinois.edu/bitstream/handle/2142/100244/Zhao-Yuxiang_20180417_V01.pdf?sequence=1\&isAllowed $=y$

Zhao, Y., \& Zhu, Q. (2012, 16-19 December). Exploring the motivation of participants in crowdsourcing contest. In Proceedings of $33^{\text {rd }}$ International Conference on Information Systems (Vol. V, pp. 3976-3988). Orlando, Florida, United States.

Zheng, H., Li, D., \& Hou, W. (2011). Task design, motivation, and participation in crowdsourcing contests. International Journal of Electronic Commerce, 15(4), 57-88.

https://doi.org/10.2753/JEC1086-4415150402

\title{
BENDRADARBIAVIMU GRINDŽIAMAS KŪRYBIŠKUMAS VYRIAUSYBËJE: KETURIŲ MOKSLINIŲ TYRIMŲ PARADIGMŲ BŪKLE்
}

\author{
Łukasz SUŁKOWSKI, Regina LENART-GANSINIEC, Svitlana BILAN
}

\section{Santrauka}

Vyriausybė, priimdama sprendimus, siekia kūrybiškumo, inovacijų, atvirumo ir piliečių ịtraukimo. Tai ịmanoma plètojant bendradarbiavimą, kuris yra komunikavimo su piliečiais priemonè ir žinių šaltinis, teikiantis naujų kūrybinių idejjų. Tačiau, nepaisant to, kad vyriausybejje intensyviai tiriamas kūrybinis bendradarbiavimas, iki šiol gauti tyrimų rezultatai vis dar tebèra neapibrěžti ir fragmentiški. Visuomenės valdymo tyrimai neretai apsiriboja interpretavimo tradicijomis. Kadangi nepaisoma trijų papildomų tyrimų paradigmų - interpretacinès, postmoderniosios ir kritinès, sudaromas neišsamus vyriausybès minètų išteklių vaizdas. Mūsų tikslas - informuoti apie daugelio paradigmų buvimą vyriausybès tyrimuose. Šio straipsnio tikslas - pristatyti bendradarbiavimą vyriausybeje iš keturių Gibsono Burrello ir Garetho Morgano išplètotų paradigmų perspektyvos. Svarstydami keturias paradigmas - pozityvistinę, interpretacinę, kritinę ir postmoderniąją, bandome ši tikslą pasiekti, pristatydami visuomenès sluoksnių valdymo apžvalgą. Teigiame, kad paskiros paradigmos nepakanka, siekiant pateikti išsamų bendradarbiavimo vyriausybẻje vaizdą, todèl ieškome sąveikų tarp paradigmų pateikdami daugiaparadigmius tyrimus, kurie galètų paskatinti tolesnę žinių plètrą.

Reikšminiai žodžiai: kūrybinis bendradarbiavimas, bendradarbiavimas vyriausybejje, daugybinė paradigma, tyrimų paradigma. 